\title{
THE EXPERIMENTAL STUDY IN THE CLASSROOM FOR THE ESTABLISHMENT OF THE ACCOUNTING STUDENTS' SOFT SKILL THROUGH EFFECTIVE TEAM BUILDING
}

\author{
Surjawati $^{1)}$, RR Dian Indriana Tri Lestari ${ }^{2)}$ \\ Faculty of Economics, Semarang University \\ ${ }^{1)}$ E-mail: surjawati19@gmail.com \\ ${ }^{2)}$ E-mail: dianindirana@usm.ac.id
}

\begin{abstract}
An accounting education graduate is required to master hard skills and soft skills. In terms of mastering soft skills in the accounting profession, it means to work together as a team. This soft skill provision is obtained through effective learning methods by forming a team that is given the assignment to solve a problem and accounts for it through presentations. The purpose of this study is to provide guidelines for lecturers to build effective teams for students. This study uses a descriptive experimental approach conducted by researchers in 5th semester students with Business Mixing Accounting courses. Team formation refers to McGrath's Model framework. This model includes the input, process, and output stages. The input phase emphasizes the quality of the teams from various inputs. The larger the team, the more personality types, and time variations will be accommodated and the more conflicts that will be faced. The stage of the process includes how members deal with conflict and make conflict a success. The output stage includes criteria for measuring group performance results and other measures such as member performance satisfaction, group cohesiveness at the end of the task, and changes in member behavior to be better.
\end{abstract}

Keywords: Soft Skill, Effective Team Building, McGrath's Model

\section{INTRODUCTION}

The mastery of soft skills and hard skills is required for an accounting graduate. The mastery of hard skills is related to the mastery of knowledge in their fields, while soft skills are the ability to work in teams, the ability to analyze and to think logically, and the ability to work in the interdependence situation. The world of work believes that superior human resources are those who do not only possess the skills of hard skills, but also an expert in soft skill aspects. Based on the survey conducted by the business community in Indonesia, graduate users need higher education graduates who have adequate soft skills than graduates who only have hard skills in the form of high intellectual intelligence.

Therefore, the educators' accountant is demanded by various professional bodies to develop the accounting students' soft skills from an early age, specifically the ability of students to work in a team. Practitioners or professionals and entrepreneurs, management accountants, public accountants, internal auditors, and the Indonesian Accountant Association, all emphasize the importance of team-building skills. The results of a survey in America conducted by the Management Accountant Association together with the Financial Accountant Association show that companies need prospective employees (accountants) who have team-building skills compared to those who do not have these skills (Segel and Sorensen, 1994 in Se Tin 2007). 
Various professional institutions and organizations have also facilitated their employees to work in teams. The American Institute of Public Accountants (AICPA) also stresses the importance of team-building among the accountants. The competencies expected from its members are personal competence, functional competence, and competence from a broad business perspective. AICPA explains that specific personal competencies are that professional accountants must be able to work in teams and have team-building skills. The aim is that accountants succeed in achieving the organizational goals, can become valuable business partners in the organization, and can provide business solutions for the organization. (AICPA, 2005) defines someone who has competence in the context of teamwork is someone who: (1) recognizes the value of diversity or differences in each person associated with their work, (2) has a commitment to achieve common goals when working in teams, (3) willing to accept advice and guidance from leaders and other members, and (4) respect and facilitate team expectations.

It is not easy to learn and practice these competencies. These competencies must be developed continuously in students so that they become habits and values that are embedded in students. Therefore, the role of lecturers is to facilitate the growth of these competencies from an early age through assignments in classrooms where the completion process by students is specifically designed by lecturers.

The application of soft skills in the classroom can be done by giving more presentation assignments and group discussions to hone the ability to communicate and to cooperate (Nina, 2008). The demands in the business world that emphasize the importance of soft skills in work, require educator accountants to provide soft skills to their students. This provision can be done in the learning process by forming a team that is given a special assignment for one semester. The learning system is done by giving more presentation assignments and group discussions.

\section{Previous Research}

This kind of research has ever been carried out by (Surjawati, Indriana, \& Nafasati, 2010) who applied the model in Advanced Accounting II in the 5th-semester students majoring in Accounting at the University of Semarang. This application is applied to the 5th-semester students with the consideration that they have already created a discussion group in the previous semester, besides that the researcher also teaches this course so that she can directly apply the application from the third meeting to the end of the lecture. The results showed that all respondents amounted to 26 students felt positive things related to the attitude changes and succeeded in reducing negative traits in themselves while they worked in the new team.

The study of (Setyawan, Priyono, \& Iswanji, 2017) applied the effective team building in the fourth-semester students majoring in accounting at Tidar Magelang University in the Financial Management course in the even semester 2016/2017. Total students who became respondents were 40 students. The assignments given to the team are projects in the form of making proposals and mini-research. The results of the application model show that the majority of respondents feel positive about the changing attitudes and succeed in reducing negative feelings while working in the new team. Respondents felt pleased and happy working in the new team and felt the significant difference between the group assignments that had been carried out and the experience of working in the new team.

(Noviyanti \& Gatot, 2010) also examined the Soft Skills Optimization of Bina Nusantara Accounting Students Through Effective Team Building: Experimental Approach. Their research analyzes the differences in team formation methods, among the team whose members are chosen by themselves without intervention from the lecturer, the team whose members are chosen by 
students with the intervention of the lecturer, and the team designed by the lecturer. The results show that the most effective method is the team formed by the lecturer.

(Fapohunda, 2013) article with the title Towards Effective Team Building in The Workplace emphasizes the importance of team building in the business world today that can be used to stimulate productivity, profitability, and quality of services provided. A team is a group of people who work together for a certain purpose. The forming of a team consists of several stages such as clarification of team goals, identification of obstacles to achieve the goals, identification of challenges, and possibilities in achieving goals.

(Saraswati \& Shilpi, 2015) from Jagannath University, Jaipur researched the title The Impact of Team Building Exercises on Team Effectiveness. The important findings in this study proved that team-building training had a positive impact on forming an effective team. The basic theory used in this study is the theory of organizational behavior that distinguishes teams and groups.

(Bryan \& Albring, 2006) created a guideline to build an effective team for accounting students by using McGrath's Model. This model covers the stages of input, process, and output.

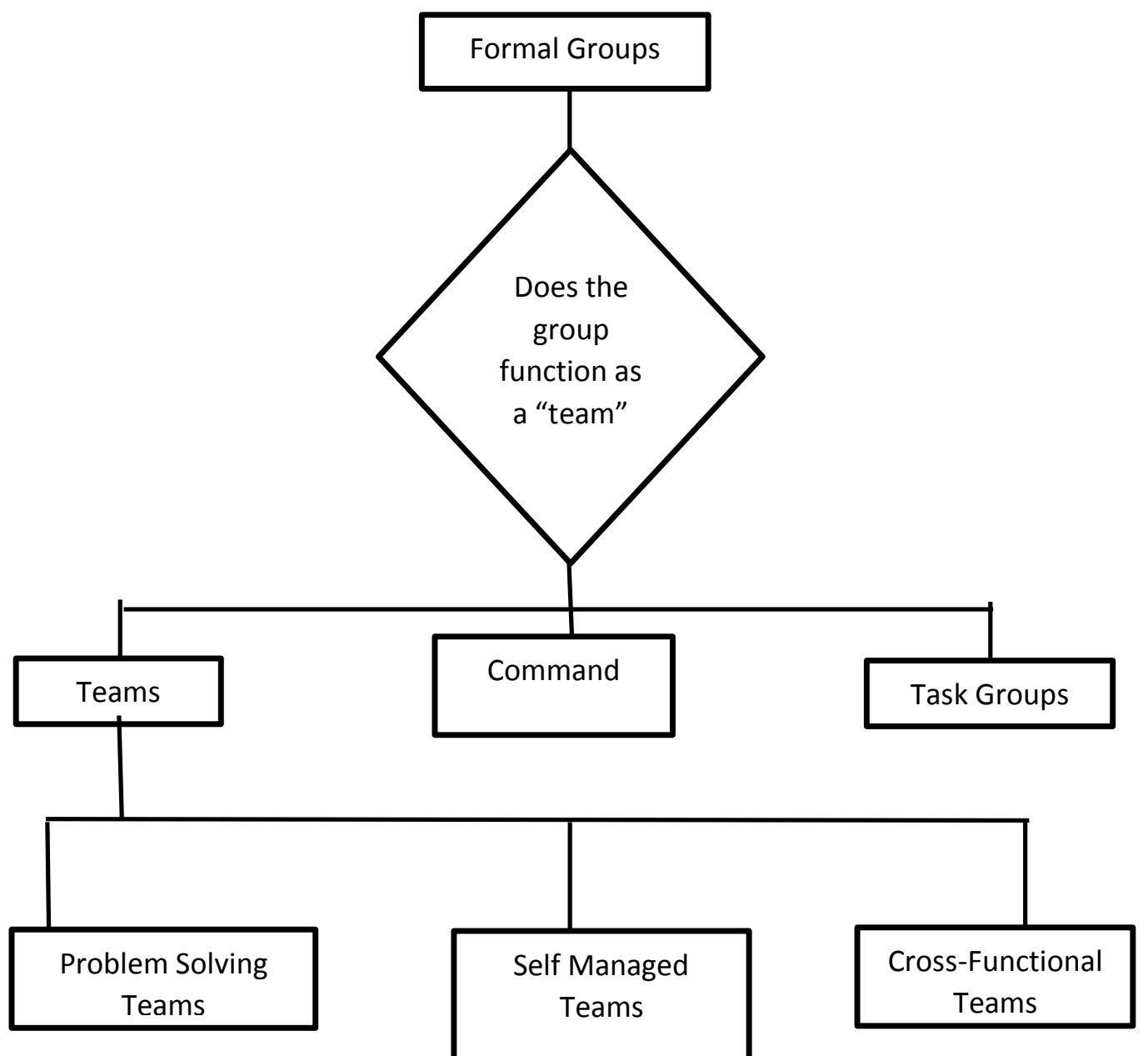

Source: Adapted from Greenberg $(1996,181)$ and Robbins (1997)

Figure 1. Groups and Teams Classification Scheme 
INPUT

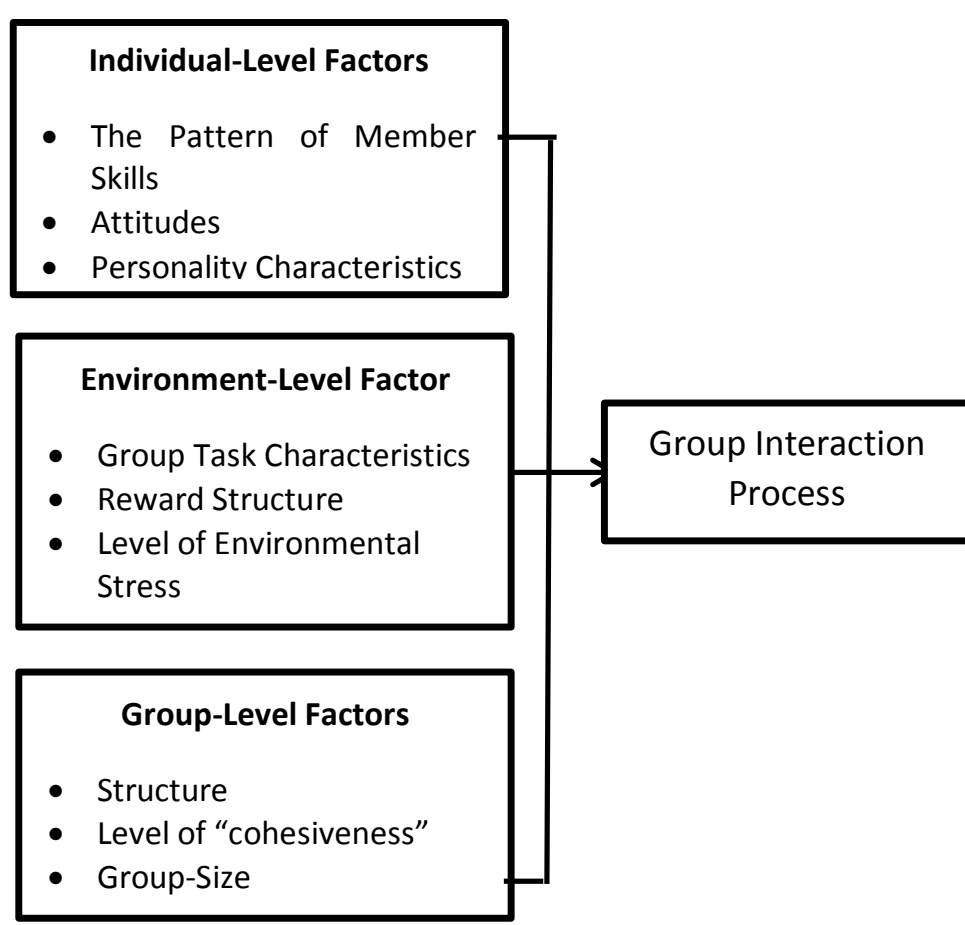

OUTPUT

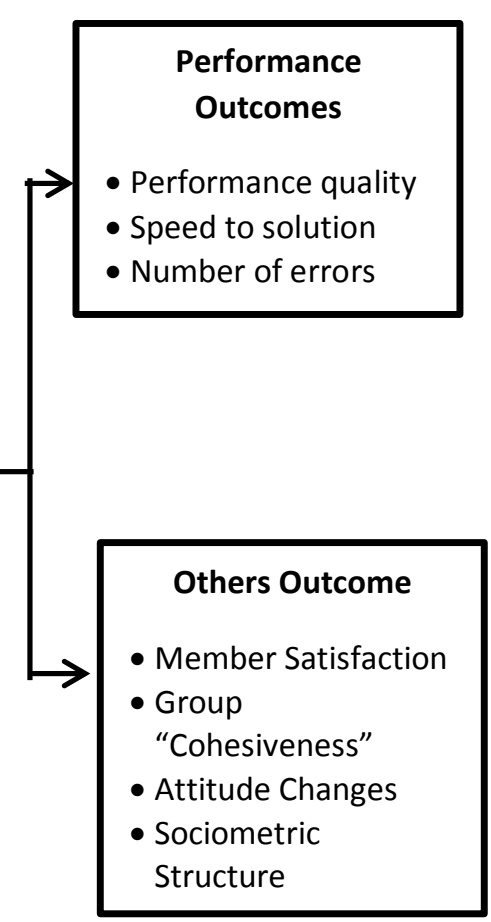

Figure 2. Mc Grath's Model of Group Effectiveness

\section{RESEARCH METHOD \\ Instrument}

The researchers provide applications by showing examples of how to build effective teams in the classroom by using McGrath's Model and following the 12-step guidelines developed by (Bryan \& Albring, 2006) and developing and modifying what the researchers did according to the conditions of the students in the classroom. These steps include:

1) Lecturers must divide the students equally into groups based on their expertise and abilities.

2) Lecturers must divide the students who do not like working in teams equally, into groups.

3) Lecturers must divide students into groups by paying attention to the aspirations/input from the students.

4) Lecturers must form teams by paying attention to gender and cultural balance.

5) Each team must form a coordinating team that is responsible to manage the team while carrying out the task, and being a mediator between the team and the lecturer.

6) The lecturer must require each team member to write and to sign a team contract in the first meeting.

7) Lecturers must form a team with the number of members from 4 to 7 people to increase individual responsibility and to reduce social loafing.

8) Lecturers must calculate the student grades based on a mixed incentive grading scheme. 
9) The lecturers must act as the team coach, providing specific guidance at the beginning, middle, and end of the assignment.

10) Lecturers must facilitate the exercises that can build an effective team so that the team can complete the tasks according to the expected time, be able to build trust among members, help them overcome the conflicts, achieve commitment and responsibility, and are interdependent and focus on the results with the high quality.

11) Lecturers must use the grading rubric to score with the belief of consistency and ranking of team results.

12) Lecturers must prepare the team and its measurement tools to measure team satisfaction.

\section{Research Subject}

The application is applied to the students majoring in Accounting who are taking the Business Mixing Accounting course at the Faculty of Economics of Semarang University. The researchers' reason chose these subjects was because they were the lecturers of the course, making it easier for the researchers to give assignments and try to practice effective team building in the classroom. The selection of the $5^{\text {th }}$-semester students as the subjects was because they had also ever worked in a team previously. The students were divided into groups with several members from 6 to 8 people. Each team will be given an assignment that they must do and present in the class. This assignment starts in the third week to two weeks before the lecture ends in that semester. Next, the team must make a report on the assignment and present the results in the class.

During one semester the lecture consists of 16 meetings, including the evaluation of the Mid Semester Exam and the Final Semester Exam. At the first meeting, the lecturer will hold a lecture contract with the students, the topic discussed is the rules of lecture for the course in one semester, syllabus courses, learning methods, books used as references, ways of evaluation and types of evaluation. At the second meeting, the lecturers explain the theory and give team assignments to the students. Then, in the third week, the students who have joined the team prepare a paper for discussion, and so on.

\section{RESULT AND DISCUSSION}

\subsection{Research Result}

The application of effective team building is implemented for the accounting students of the $5^{\text {th }}$-semester of Semarang University who are taking the Business Mixing Accounting course. The total students who became respondents were 149 students who were divided into 3 classes, they are A, B, and C. The project provided was making paper and clipping about Business Mixing.

In each class the students are divided into 8 groups, each group consists of 6 to 8 students. The distribution of the students into each group was intervened by the lecturers with the help of the class leaders. The team formation takes into account individual-level factors and group-level factors. Individual-level factors include the abilities, attitudes, and personality traits and aspirations or input from the students. Group level factors include gender and cultural balance structures, and the appointment of a team coordinator and group size. After the team is formed, to get a better recognition among the team members can be obtained at the time of giving the assignment that must be done as a team. The task as a team began to be presented at the third meeting, namely the task of the first team, to make a paper on Business Mixing. 
Project assessment uses a mixed incentive model, where the lecturers give scores for each team paper and individual score for the presentation so that each member will get a different score. In the last meeting of the lecture, the best team was selected in each class and the best team was given appreciation by the lecturer.

At the end of this team-building process, the students are asked to fill out forms containing questions about: (1) their feelings in completing this project with a new team; (2) the real difference felt between group assignments that have been carried out so far with the experience of working on a new team; (3) the positive things related to attitude changes experienced in the new team; (4) negative things that have been eliminated or reduced while working on the new team; (5) their opinion about the characteristics of the ideal team and (6) what steps the lecturers should improve in forming a team.

\subsection{Discussion}

The followings are the results of the final section in the team-building process that contains the questions answered by the respondents.

\section{Question 1:}

How do you feel about completing a project with a new team?

\begin{tabular}{|ccc|}
\hline Amount & Happy & $\begin{array}{c}\text { Unhappy/ Displeased/ } \\
\text { Uncomfortable }\end{array}$ \\
\hline Respondent & 133 & 16 \\
\hline Percentage & $89,26 \%$ & $10,74 \%$ \\
\hline
\end{tabular}

The results of the study prove that as many as $10.74 \%$ of respondents, namely 16 out of 149 respondents described that they felt awkward, uncomfortable, and were less able to work in a new team. Meanwhile, as many as $89.26 \%$ or 133 out of 149 respondents stated that they liked working in the new team for various reasons which can be summarized as follows:

1. Can learn to understand the different characters of friends.

2. Get a lot of new experiences.

3. Can cooperate well.

4. Unified.

5. Get different insights.

6. Get a new challenge.

7. Every team member participates actively.

8. The task is completed well and on time.

9. Comfortable.

10. Can bring different thoughts together 
International Journal of Economics, Business and Accounting Research (IJEBAR)

Peer Reviewed - International Journal

Vol-4, Issue-3, 2020 (IJEBAR)

E-ISSN: 2614-1280 P-ISSN 2622-4771

http://jurnal.stie-aas.ac.id/index.php/IJEBAR

\section{Question 2:}

What is the real difference felt by the respondents between the group tasks that have ever been carried out and the respondent's experience in working with a new team?

\begin{tabular}{|ccc|}
\hline Amount & There is a significant difference & There is no significant difference \\
\hline Respondent & 138 & 11 \\
\hline Percentage & $92,62 \%$ & $7,38 \%$ \\
\hline
\end{tabular}

The findings in this study were $7.38 \%$ of respondents, namely 11 out of 149 respondents stated that there was no significant difference between the experiences in the groups they had lived with and the new team. While $92.62 \%$ of respondents, namely 138 out of 149 respondents stated that there were significant differences in doing the previous group tasks and working in a new team. They argue that in the new team they feel:

1. More motivated.

2. There is a fair distribution of tasks.

3. Do the task effectively.

4. Help one another.

5. More discipline.

\section{Question 3:}

What positive things (related to attitude changes) obtained/felt by the respondents while working in a new team?

\begin{tabular}{|lcc|}
\hline Amount & Experiencing positive things & No answer \\
\hline Respondent & 148 & 1 \\
\hline Percentage & $99,33 \%$ & $0,067 \%$ \\
\hline
\end{tabular}

Based on the results of the study, there was 1 respondent who did not comment on this question, as many as 148 respondents stated that they experienced positive things related to the formation of the new team. These positive things can be summarized as follows:

1. Getting to know a friend's character.

2. More diligent, discipline, on time, and active.

3. More confidence during the presentation.

4. More responsibility.

5. More solid.

6. More patients and can suppress the ego.

7. More able to work with teammates.

8. More enthusiasm for learning.

9. Having initiative.

10. A more open mind.

11. Better communication.

12. More adaptable.

13. Easier to understand the material. 
International Journal of Economics, Business and Accounting Research (IJEBAR)

Peer Reviewed - International Journal

Vol-4, Issue-3, 2020 (IJEBAR)

E-ISSN: 2614-1280 P-ISSN 2622-4771

http://jurnal.stie-aas.ac.id/index.php/IJEBAR

\section{Question 4:}

What negative things have been eliminated/reduced successfully while working in a new team?

\begin{tabular}{|c|c|c|}
\hline Amount & $\begin{array}{c}\text { Answers relevant to the } \\
\text { questions }\end{array}$ & Answers irrelevant to the questions \\
\hline Respondent & 143 & 6 \\
\hline Percentage & $95,97 \%$ & $4,027 \%$ \\
\hline
\end{tabular}

The results of the study showed as many as 143 respondents or as many as $95,97 \%$ of respondents stated that they successfully eliminated the negative traits after they joined the new team. While 6 respondents, or equal to 4, $027 \%$ of respondents gave answers that were not relevant to the question. The negative things that have been eliminated or reduced successfully while working in a new team can be summarized as follows:

1. The nature of delaying work.

2. Unconfident.

3. Selfish.

4. Shy.

5. Irresponsible.

6. Unrespect the opinions of friends.

7. Lazy.

8. Less able to mingle with friends.

9. Depends on friends (dependent).

10. Doing tasks using the overnight speeding system.

11. Quiet / lack of communication.

12. Lack of discipline.

13. Emotional.

14. Impatient.

15. Dominant.

16. Lack of enthusiasm.

17. Ignorant.

\section{Question 5:}

What do you think about the characteristics of the ideal team?

\begin{tabular}{|ccc|}
\hline Amount & Giving opinion & Do not give an opinion \\
\hline Respondent & 100 & 0 \\
\hline Percentage & $100 \%$ & $0 \%$ \\
\hline
\end{tabular}

The results of the study explained that $100 \%$ of respondents gave their opinions on this question. In general, their opinions about the ideal team are related to good things, which can be summarized as written below. According to them, the ideal team is a team that:

1. Team members try to understand the character of friends, help each other and cooperate, responsible, mutual understanding among the team members. 
2. Good team leadership.

3. Good communication.

4. Unified and trust each other.

5. Share tasks, discuss, and try to achieve common goals.

6. Punctual in completing assignments.

7. Can suppress the ego.

8. Tolerant with the others.

9. Complementing each other.

10. Good coordination.

\section{Question 6:}

What scenarios that must be improved by the lecturers in forming a team?

\begin{tabular}{|lccccc|}
\hline Amount & No opinion & $\begin{array}{c}\text { Irrelevant } \\
\text { answer }\end{array}$ & $\begin{array}{c}\text { Team was chosen } \\
\text { by students }\end{array}$ & Randomized & Good \\
\hline Respondent & 6 & 14 & 5 & 15 & 109 \\
\hline Percentage & $4,03 \%$ & $9,39 \%$ & $3,36 \%$ & $10,07 \%$ & $73,15 \%$ \\
\hline
\end{tabular}

The results of this study contained 6 respondents who did not give opinions, 14 respondents gave answers that were not relevant to the question, 5 respondents still wanted team members to be chosen by students themselves, 15 respondents thought that the team selection scenario by lecturers needed to be randomized and 109 respondents stated that the team organized as well.

\section{CONCLUSION}

Based on the application results of forming an effective team on 3 classes of accounting students in Business MixingAccounting course, the following conclusions can be drawn:

1) Respondents thought that they felt awkward when cooperated in the new team for the first time by less than $11 \%$, while around $89 \%$ felt happy and experienced positive things during cooperated in the new team.

2) Respondents stated that there was no significant difference between the new team and the team they had felt before by less than $8 \%$, while more than $92 \%$ of respondents stated that they experienced the significant difference between the new team and the previous team. In the new team, they feel more motivated to cooperate, gain new insights, and can understand the character of different friends better.

3) Respondents experienced positive things while cooperating with the new team, such as they felt more energized, more able to suppress selfishness, learn to be more patient, gain insight, be more open-minded, and so on by almost $100 \%$. Besides, they also succeeded to eliminate negative traits, such as being unpunctual, being selfish, impatient, unconfident, and other negative traits.

4) Respondents gave opinions about the formation of an ideal team of $100 \%$. According to them, the ideal team is a team in which there are: (a) Mutual understanding of the characteristics among the team members, (b) Good leadership, (c) Mutual tolerance, (d) Good communication, (e) Having the same opinion in achieving common goals, (f) Unified and trust each other. 
Based on the research results, it can provide urgency for:

1) Lecturers who are teaching in Accounting department

The results of this study can be used as guidelines for the lecturers in the accounting department in forming a team. The formation of the team in the course being taught can refer to the 12 steps that have been carried out in this study.

2) Managers of Accounting Department

To apply this research properly, the managers of the Accounting department must equate the perceptions about the importance of soft skills provision for the accounting students. If there is a common perception, then the concept of team building can be done in all courses where the learning method is by carrying out team building.

This research has a limitation, namely this research has not compared the design of a team based on McGrath's Model (a team designed by the lecturer) with a team design based on a selforganizing system (students choose their members and manage their groups without the intervention from the lecturer). Therefore, for further research, it is recommended to apply the team with two different designs, based on McGrath's Model and based on self-organized system, and the results can be compared.

\section{REFERENCES}

AICPA. (2005). American Institute of Certified Public Accounting Core Competence . http://www.aicpa/org/edu/corecomp.htm.

Bryan, S., \& Albring. (2006). Effective Team Building : Guidance for Accounting Educator. Journal of Accounting Education.

Fapohunda, T. M. (2013). Toward Effective Team Building The Workplace. International Journal of Education 1(4), 1-12.

Noviyanti, \& Gatot, S. (2010). Optimalisasi Softskill Mahasiswa Akuntansi UBINUS Melalui Effective Team Building : Pendekatan Eksperimental. Binus Business Review 1(1), 5065.

Saraswati, M., \& Shilpi, K. (2015). Impact of Team Building Excercises on team Effectiveness. International Journal of Marketing and Human Resource Management. 6(1), 89-96.

Setyawan, S., Priyono, N., \& Iswanji, C. (2017). Pembentukan Softskill Mahasiswa Akuntansi Melalui Effective Team Building dalam Kelas : Sebuah Aplikasi McGrath Model.

Surjawati, Indriana, D., \& Nafasati, F. (2010). Membentuk Softskill Mahasiswa Akuntansi Melalui Effective Team Building dalam Ruang Kelas.

Sutrisno, B. (2017). Profil Model Pembelajaran Softskill pada SMK Bidang Ekonomi di Surakarta.

Zahroti, E. N. (2015). Membentuk Softskill Mahasiswa Akuntansi Melalui Effective Team Building dalam Ruang Kelas. 